Leszek Loroch, Adam Okniński, Grzegorz Rarata, Pawel Surmacz, Mariusz Kacprzak, Mariusz Krawczyk, Dawid Cieśliński, Kamil Sobczak, Piotr Wolański

Instytut Lotnictwa, Centrum

Technologii Kosmicznych, Warszawa

Corresponding author: Leszek Loroch, leszek.loroch@ilot.edu.pl

DOI: 10.35117/A_ENG_18_01_06

\title{
Space technology at the Institute of Aviation
}

\begin{abstract}
This paper gives a brief summary of the Institute of Aviation's activities in space technology. Review of historical achievements and latest developments are described. Scope of present work of Space Technology Center and key projects are discussed, that include rocket and satellite technologies. Importance of space technologies in Institute of Aviation's development strategy and their crucial role for safety and independence of the state is underlined. Possibilities and future use of the developed technologies are pointed out.
\end{abstract}

Keywords: Space technology; Rocket technology; Satellite technology

\section{Introduction}

The development of space technologies is of fundamental importance for the security and functioning of the state, as evidenced by the interest in using them by many ministries and government executive agencies [12]. The strategy of the Space Technology Center at the Institute of Aviation for the coming years assumes the implementation of research and development works in the fields:

- Development and testing of rocket engines (one- and two-component) for liquid, hybrid, gas, and gel propellants with reduced toxicity, mainly with hydrogen peroxide as an oxidant and the development of new single-component propellants from the group of socalled HPGP (High-Performance Green Propellants)

- development of engines for solid propellant (among others through new compositions of solid grains of composite propellants)

- development of rockets with space or military applications, including the development of sounding and carrier rocket components and subsystems

- development of engine technology for satellite de-orbiting

- development of computers and electronic systems for rockets, including elements of ground facilities

- development of satellite remote sensing and increasing the area of its applications

Currently, the most intense work is underway in the field of rocket technology, where efforts are focused on the development of modern power units, mainly using ecological rocket propulsion. Although rocket propulsion works have been ongoing at the Institute of Aviation since 2007 , history dates back to the 1960 s $[6,20]$.

\section{History of the development of space technologies at the Institute of Aviation}

The Institute of Aviation has been working on space technology for over 50 years. The first projects were directly related to missile technologies. In particular, the Meteor sounding rocket 
program should be distinguished [18]. The largest tested rocket - Meteora 2K - has reached a conventional space limit.
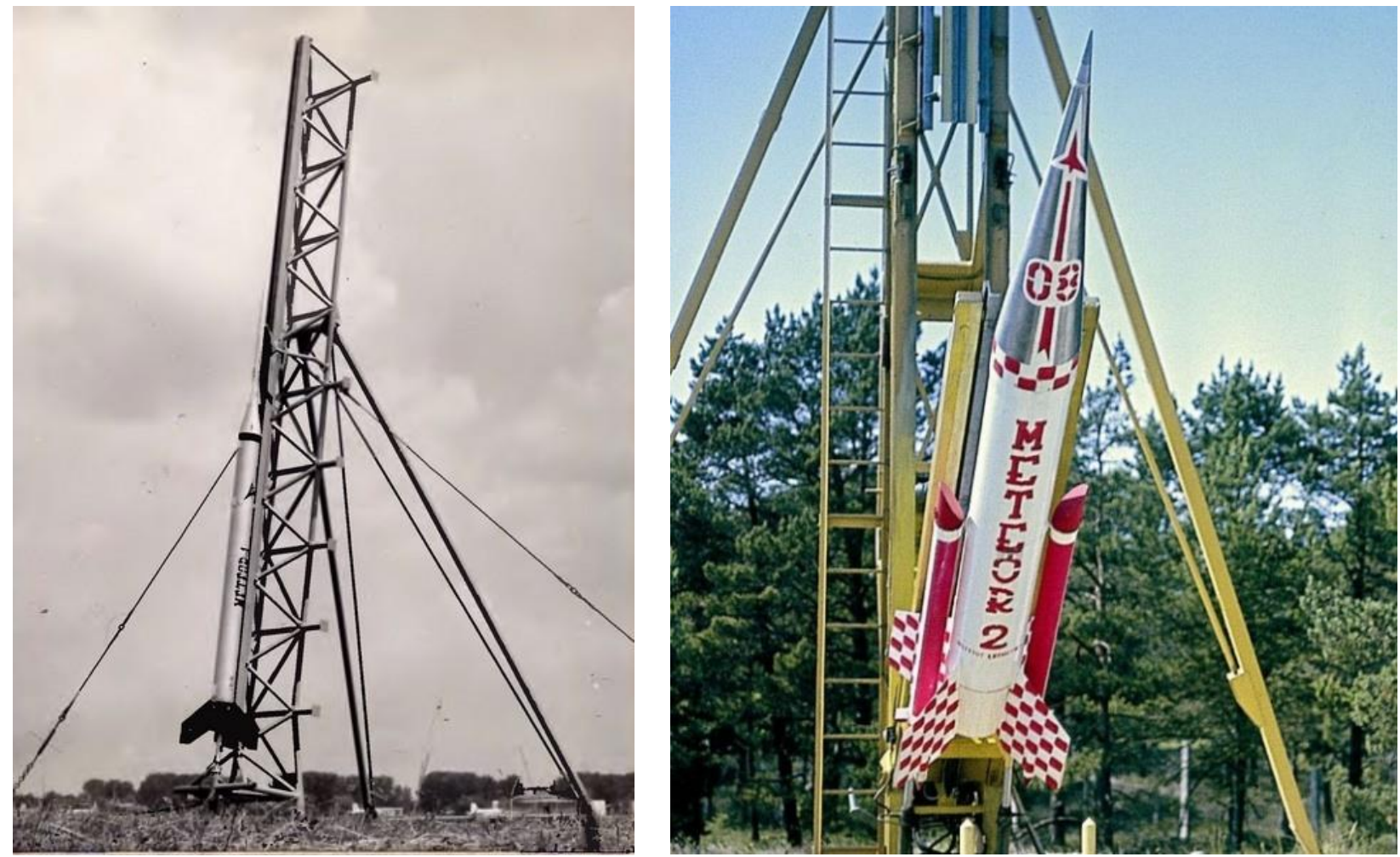

1. Meteor 1 rocket and Meteor $2 \mathrm{~K}$ rocket

In the early 1970s, the Institute of Aviation developed satellite equipment as part of the INTREKOSMOS program. Fig. 2 shows SAWA BUD A apparatus, which was on board the Prognoz-8 mission. A much wider list of achievements of engineers from the Institute of Aviation in the field of development of satellite and terrestrial devices in the Soviet programs (Interkosmos 15, Interkosmos 19, Vega, Phobos) can be found in the source [20].
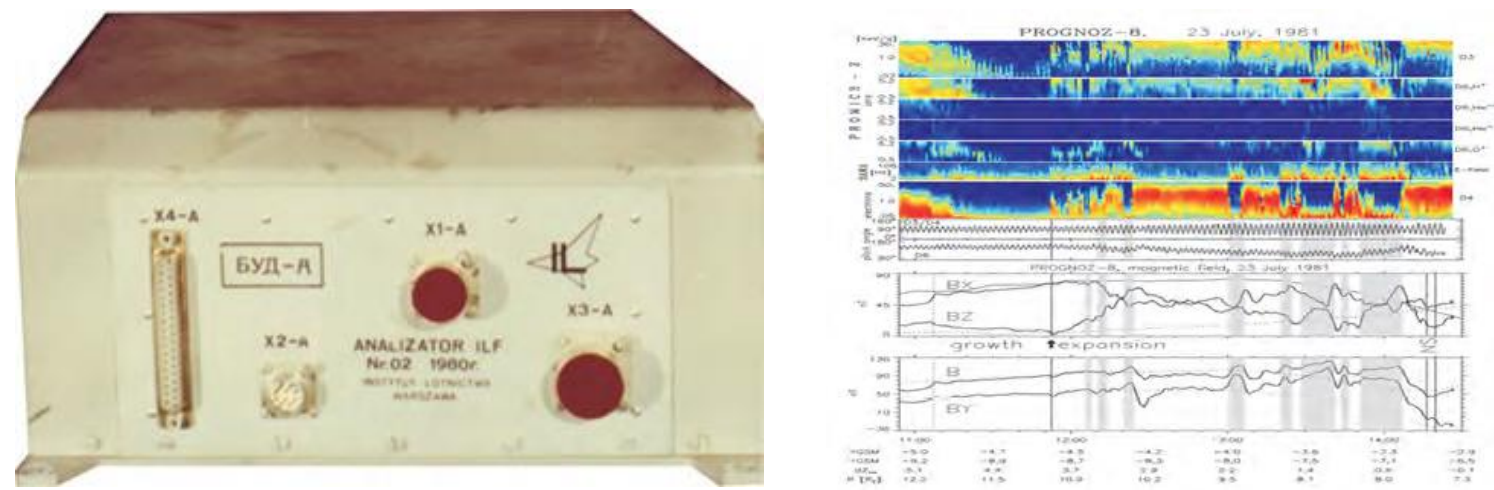

2. "SAWA BUD A" apparatus for the analysis of the plasma wave spectrum in the $2-105 \mathrm{~Hz}$ range [20] 
In the 1980s and 1990s, space technology activities were minimal. A landmark event was the establishment of a rocket technology facility in 2007. Over the next few years, the Space Technology Center was established, which in 2017 employs 80 employees implementing projects under four plants.

\section{Satellite remote sensing}

The Department of Remote Sensing (ZT) of the Institute of Aviation was established on the basis of the HESOFF project implemented since 2013, financed by the European Commission (LIFE + instrument) and the National Fund for Environmental Protection and Water Management (NFOŚiGW). One of the main objectives of the project is to develop methods for remote monitoring of the forest and the condition of individual trees without having to conduct costly field tests.

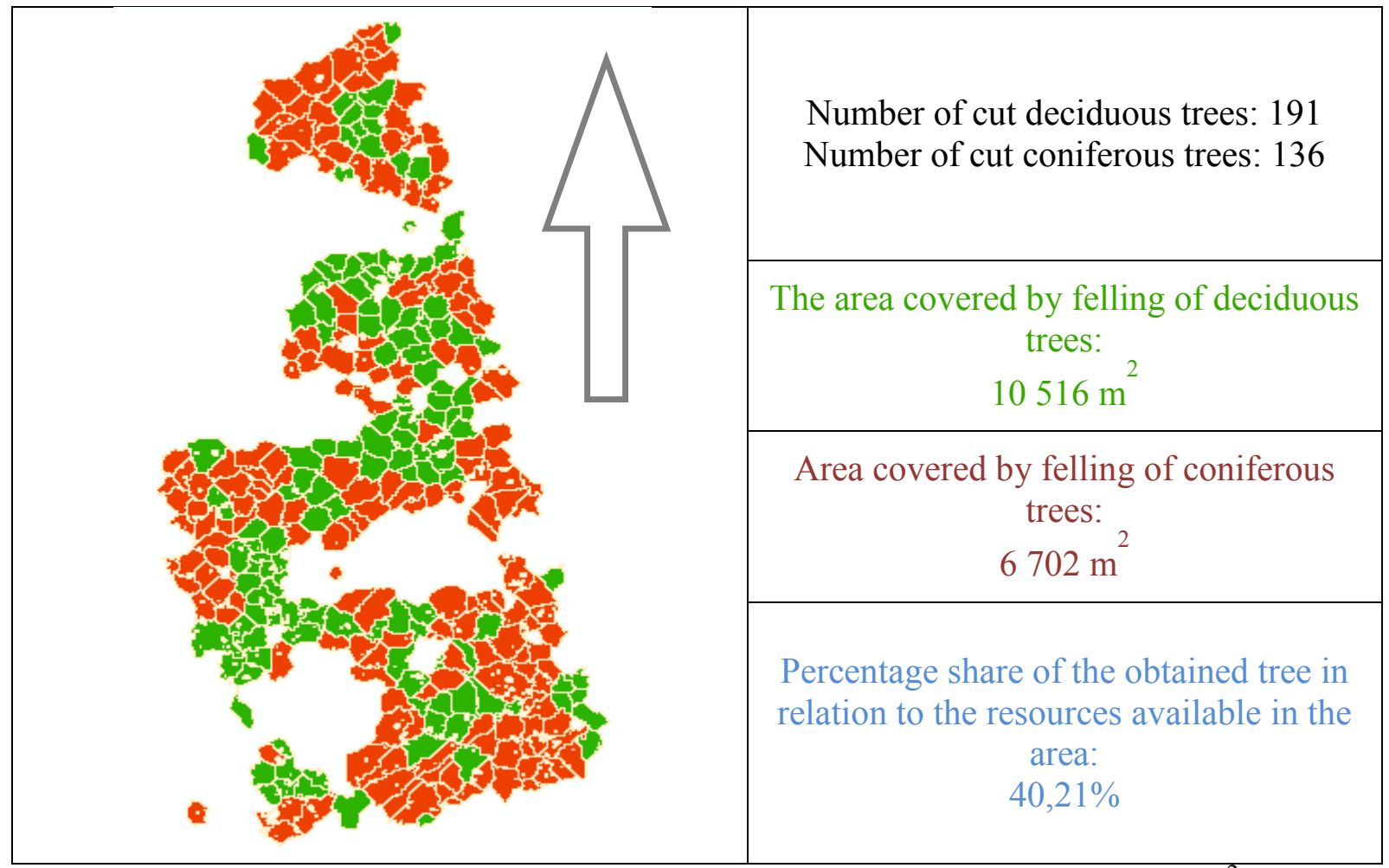

3. Remote sensing analysis of the indicated area with an area of $25,000 \mathrm{~m}^{2}$

The Department of Remote Sensing is involved in works that include both image acquisition and operational processing [1, 2, 3, 5]. Photographs are made with the use of commercial equipment and the Multispectral System (6-ranges) developed for the needs of the HESOFF project. Photogrammetic specialists will prepare a flight plan based on designated boundary conditions, which determine the expected quality and interpretation potential of aerial and satellite image processing products. Optical systems are mounted on both the deck of manned and unmanned aerial vehicles. In the years 2014-2016, over 30 photographic missions were conducted, in the course of which over $300 \mathrm{~GB}$ of source photos were acquired. In addition, the Remote Sensing Department has the ability to directly download satellite scenes distributed in the EumetCAST network, work is underway to obtain direct access to the Sentinel deployment database. The area of specialization of employees of the Remote Sensing Department includes 
photogrammetry, remote sensing, geology, biology, geography, mechatronics, physics, and Big Data. The plant has modern commercial remote sensing and photogrammetry software. The full production line allows for the operational processing of photos into the form of an orthophoto map and the Numerical Terrain Coverage Model, which can then be used for, among others, creating vector layers, among others for the needs of dedicated spatial information systems (SIP). The important thing is that in addition to specialized remote sensing software, proprietary algorithms and programs for data processing are used.

The basic ZT infrastructure consists of: modern sensors for acquiring numerical data and images (visible and infrared range), spectrometers for acquiring spectral curves, computational cluster, data warehouse, technical apparatus for direct download of satellite scenes and a matrix of eight monitors for data visualization. The result of research and development carried out so far is, among others development of procedures for data acquisition and processing, and proprietary algorithms for image analysis. High quality of studies supported by scientific publications is a significant competitive advantage in relation to the studies carried out by commercial companies operating on the market.

\section{Rocket technologies}

Highly concentrated hydrogen peroxide (HTP) is a strong liquid oxidant (the second one after liquid oxygen) and, at the same time, the relatively safest one-component propellant. It is also a universal, extremely environmentally friendly medium, currently having an increasingly widespread application not only in rocket technology, which is, moreover, the subject of research by the Department of Space Technology at the Institute of Aviation. HTP peroxide, until recently was practically unavailable on the European market, especially in smaller quantities. As a result, academic centers and research and development units that could take care of HTP research were not able to acquire even small amounts of HTP at a reasonable price. Therefore, the Institute of Aviation has developed a technology for obtaining from laboratory to technical quantities of relatively cheap hydrogen peroxide with a concentration of over $90 \%$ and a sufficiently high purity. This technology has been commercialized, and 98\% HTP produced using it, including in the European Space Agency (ESA) research projects. Currently, it is possible to produce hydrogen peroxide in larger quantities. The technology developed at the Institute of Aviation enables the production of HTP grade hydrogen peroxide, including $98 \%+$ (for "Rocket Grade Hydrogen Peroxide" propulsion applications) [19].

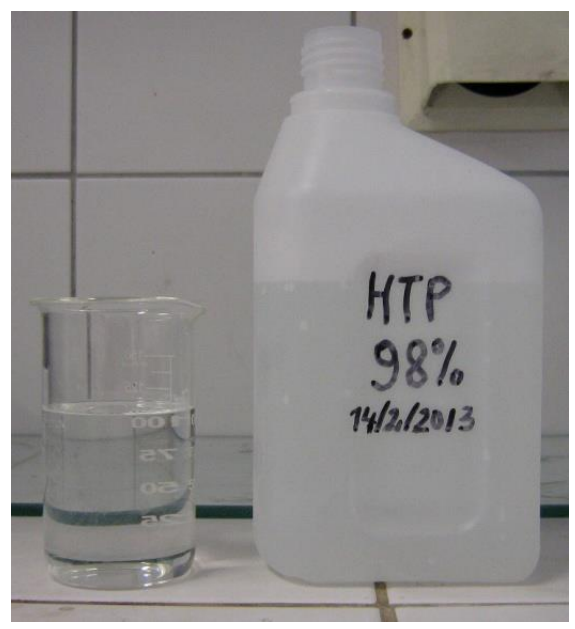

4. Sample $(1 \mathrm{~L})$ of $98 \%$ HTP grade hydrogen peroxide 


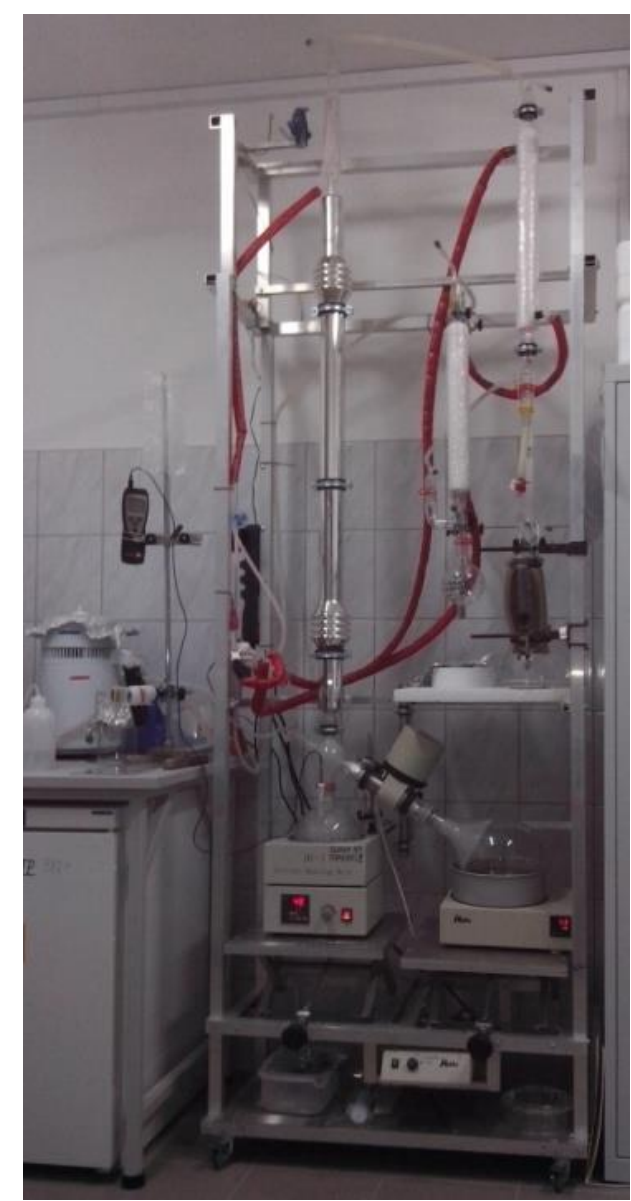

5. Laboratory stand for preparation of $98 \%+$ HTP grade hydrogen peroxide

Since 2012, the Institute has started testing of rocket engines using HTP class peroxide. The first stage is the development of heterogeneous catalysts based on A12O3 with the active phase plotted at the Institute of Aviation [15]. Catalysts allow the decomposition of hydrogen peroxide and the release of a large amount of heat. In the first phase of competence development, work was carried out on rocket propulsors (single-component, two-component and hybrid) with thrust forces ranging from 10 to $500 \mathrm{~N}[13,14,16]$. From 2015, work began with much larger units. Engine tests of up to $6,000 \mathrm{~N}$ were carried out $[9,10,11]$. Currently, the projects carried out at the Institute of Aviation concern rocket engines with thrust ranging from 1 to 50,000 N. Some of them could be used as part of the development of a small carrier rocket.

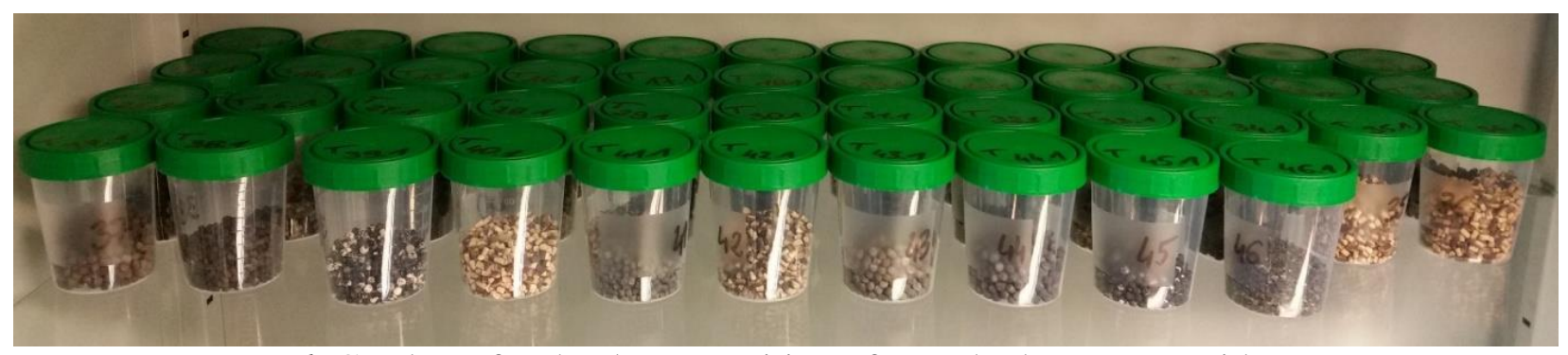

6. Catalysts for the decomposition of HTP hydrogen peroxide 


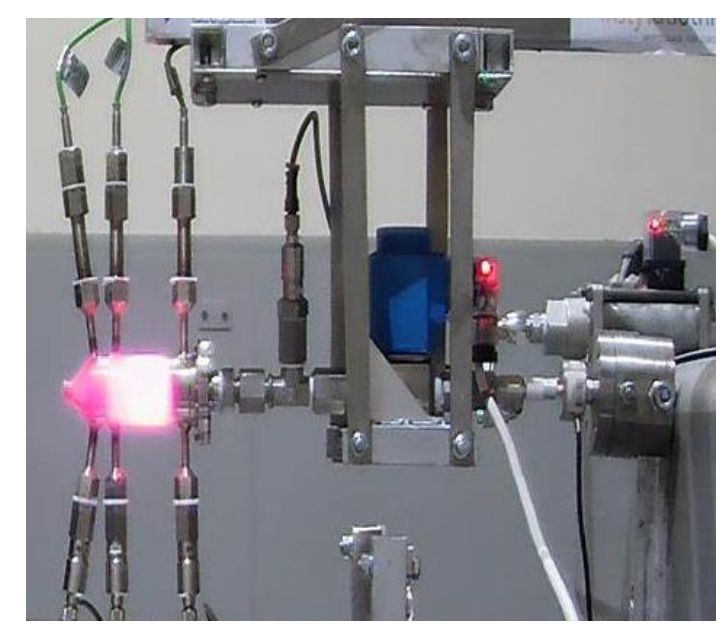

7. Motor for single-component propellant

However, the step preceding the possible development of a carrier rocket is a demonstration of key technologies on the suborbital rocket. The first works were carried out at the Warsaw University of Technology [8]. Further development of the sounding rocket market [4] led to the decision to launch the sounding platform demonstrator project at the Institute of Aviation [7]. The ILR-33 "Amber" rocket is an innovative test platform enabling the verification of key technologies in flight The state of the project in August 2017 includes the verification of a number of subsystems in ground conditions and tests of individual components as part of volatile field trials. from the European Space Agency and allowed to strengthen the cooperation of the Institute of Aviation with ESA.

In addition to mechanical subsystems, the Aviation Institute develops advanced avionics and systems for controlling executive systems. An example of a technology demonstrator is the on-board demonstrator of the ILR-33 "Amber" rocket, which is being developed at the Avionics Plant [17], allowing telemetry analysis from the rocket in real time at the ground control station. up to $+60^{\circ} \mathrm{C}$ and pressure range from 0 to $1200 \mathrm{hPa}$ at humidity up to $100 \%$ It withstands the following vibrations: $10 \mathrm{~g} / 20 \mathrm{~Hz}-20 \mathrm{kHz}$ and acceleration in the main axis up to $1000 \mathrm{~g}$. The frequency of data recording is $500 \mathrm{~Hz}$.

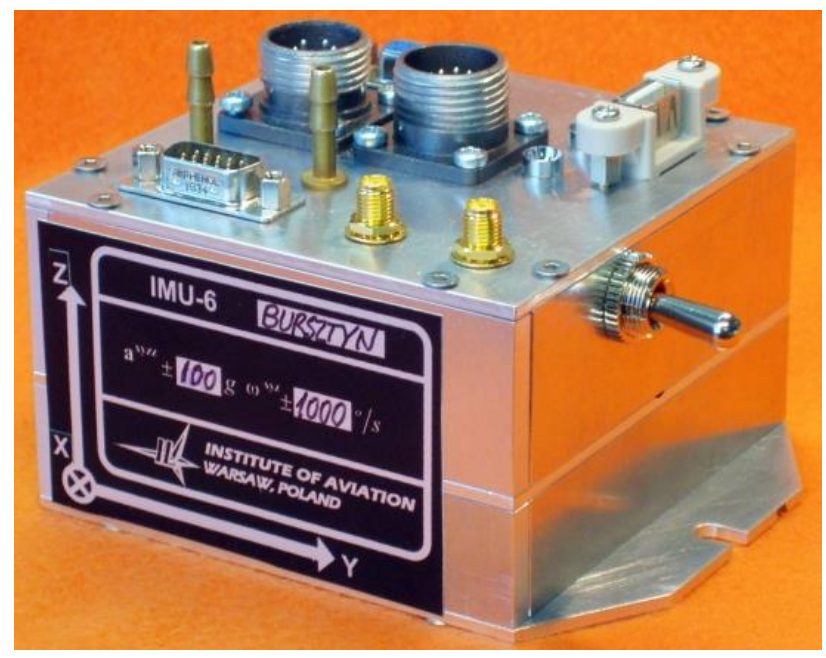

8. The ILR-33 rocket board computer "Amber" 
Advances in rocket propulsion and new technologies enable the engineering team to contribute to the development of launcher technology. The first concepts were created already in 2005 [21], while in 2016, the first project of the European Space Agency was implemented, which concerned only the launch of missiles.
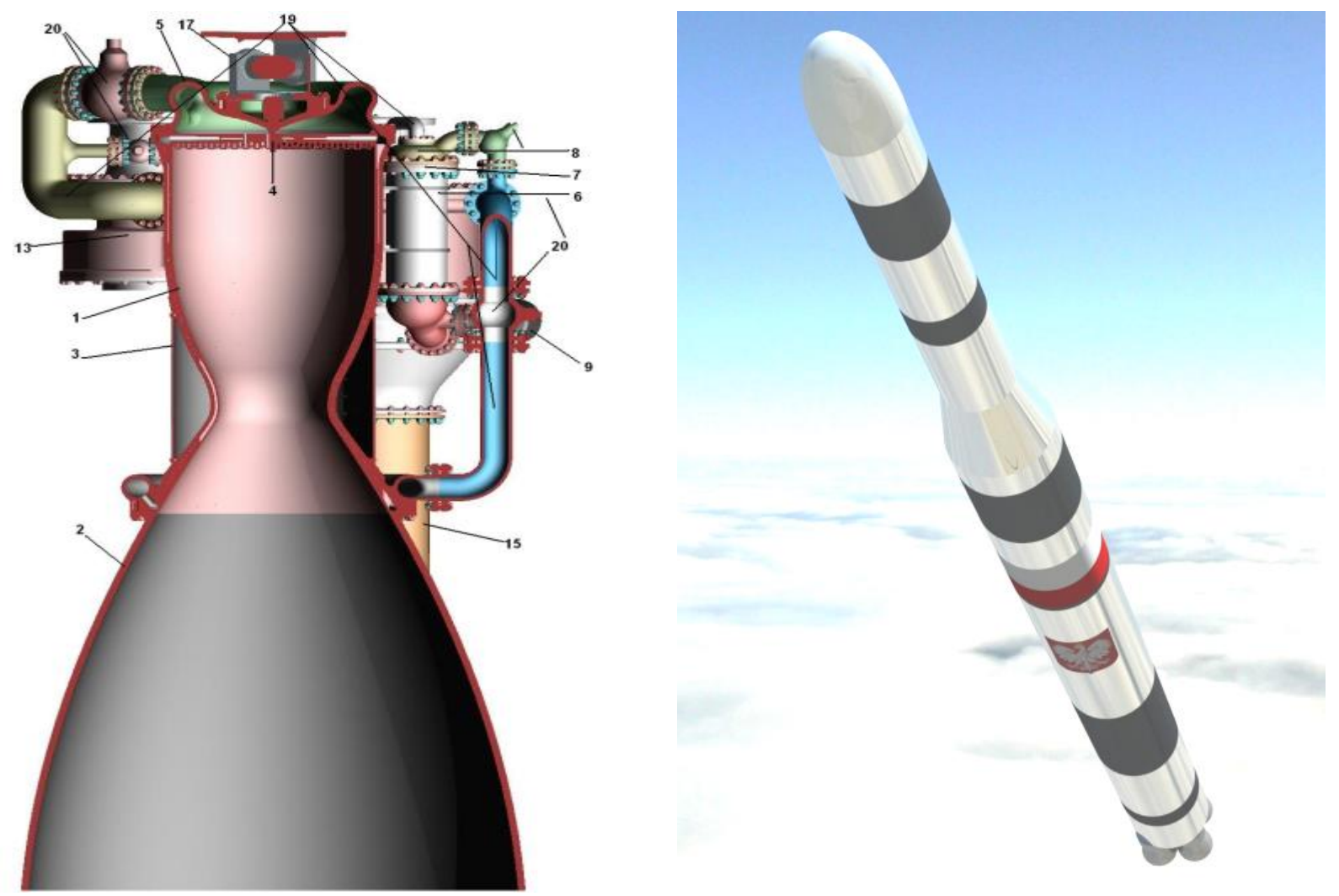

9. Pre-project of a rocket engine for driving a small rocket, concept of a rocket

\section{Summary}

Conducted in the Institute of Aviation, works in the field of space technologies allowed the development of research infrastructure and a research team enabling the implementation of large external projects. Participation in the programs of the National Center for Research and Development, the European Commission and the European Space Agency ensured the strengthening of existing forms of cooperation with Polish and foreign entities. It is worth noting that the Institute of Aviation is the leader of a number of projects received from the European Space Agency, including projects received as part of open competitions. However, successes on the European market would not have been possible without the statutory projects that would allow the technological readiness of developed solutions to be raised and the attractiveness of the Institute of Aviation as the contractor for external research and development projects. The development of the team's competence and constantly expanded, as part of statutory and external portfolio projects, allow the Institute of Aviation to approach the development of volatile components of space missions of new generations of satellites and missiles. 


\section{Acknowledgments}

The authors would like to thank colleagues from the Space Technology Center of the Institute of Aviation who participated in the described projects and shared their experience, facilitating the preparation of this publication.

\section{Source materials}

[1] Czapski P. et Al. Pozyskiwanie i przetwarzanie danych lotniczych i satelitarnych przez. zespół badawczy Zakładu Teledetekcji Instytutu Lotnictwa, Przegląd Geodezyjny 88 (3), 49

[2] Czapski P. et Al. Preliminary analysis of the forest health state based on multispectral photos acquired by Unmanned Aerial Vehicle, Folia Forestalia Polonica 57, nr 3 (2015): 138-144.

[3] Czapski, P. et Al. Budowa i zastosowanie platformy wielosensorowej w badaniu wybranych parametrów środowiska, Prace Instytutu Lotnictwa, vol. 1(234), 2014, s. 126-142.

[4] Davidian, K., Foust, J. Suborbital Market Overview and Application of Disruption Theory, IAF, Prague, 2010, IAC-10-E6.3.8

[5] Kacprzak, M., Wodziński, K. Realizacja misji fotolotniczych z wykorzystaniem załogowych $i$ bezzałogowych statków powietrznych, Prace Instytutu Lotnictwa, vol. 2(243), 2016, s. 130-141.

[6] Loroch, L., Rams, L. Infrastruktura badawcza oraz struktura organizacyjna Centrum Technologii Kosmicznych Instytutu Lotnictwa, Prace Instytutu Lotnictwa, 2014, Vol. 234, 1, pp. 17-24, doi: 10.5604/05096669.1106737.

[7] Marciniak, B. et Al. Development of ILR-33 Amber sounding rocket for microgravity experiments Proceedings of the International Astronautical Congress, IAC, Jerusalem, 2016

[8] Marciniak, B. Okninski, A. Rozwój polskiego programu rakiet sondujacych, Transactions of the Institute of Aviation, Vol. 234(1), 2014, pp. 73-81, doi: 10.5604/05096669.1106782

[9] Nowakowski P. et Al. Development of Small Solid Rocket Boosters for the ILR-33 Sounding Rocket, Acta Astronautica, Volume 138, September 2017, pp. 374-383, doi:doi.org/10.1016/j.actaastro.2017.06.007

[10] Okninski, A. et Al. Development of a Small Green Bipropellant Rocket Engine Using Hydrogen Peroxide as Oxidizer, Cleveland, OH: 50th AIAA/ASME/SAE/ASEE Joint Propulsion Conference, 2014. AIAA-2014-3592, DOI: 10.2514/6.2014-3592.

[11] Okninski, A. et Al. Development of the Polish Small Sounding Rocket Program, Acta Astronautica. March-April, 2015, Vol. 108, pp. 46-56, doi:10.1016/j.actaastro.2014.12.001.

[12] Sektor Kosmiczny w Polsce, https://www.mr.gov.pl/strony/zadania/reindustrializacjagospodarki /polityka-kosmiczna/sektor-kosmiczny-w-polsce, strona odwiedzona 11 sierpnia 2017.

[13] Surmacz, P. Green Rocket Propulsion Research and Development at the Institute of Aviation: Problems and Perspectives, Journal of KONES, 2016.

[14] Surmacz, P. Influence of Various Types of Al2O3/MnxOy Catalysts on Performance of a $100 \mathrm{~mm}$ Chamber for Decomposition of $98 \%+$ Hydrogen Peroxide, Prace Instytutu Lotnictwa, vol. 240, 2015.

[15] Surmacz, P., Rarata G. Badanie katalitycznego rozkładu 98\% nadtlenku wodoru $z$ wykorzystaniem katalizatorów Al2O3/MnxOy, promowanych tlenkami metali przejściowych, Prace Instytutu Lotnictwa, nr 234, 2014. 
[16] Surmacz, P., Rarata, G. Prace badawcze i rozwojowe nad demonstratorem technologii rakietowego silnika hybrydowego, wykorzystujacego 98\% nadtlenek wodoru jako utleniacz, Prace Instytutu Lotnictwa, nr 234, 2014.

[17] Szpakowska-Peas, E., Krawczyk, M. Selected problems of electronic equipment design in rocketry, Transactions of the Institute of Aviation, Vol. 245 (4), 2016, pp. 209-217, doi: 10.5604/05096669.1226892

[18] Walczewski, J. Polskie rakiety badawcze, Biblioteczka Skrzydlatej Polski, tom XV, WKIL, Warsaw, 1982.

[19] Wiśniowski, W. Specjalizacje Instytutu Lotnictwa-przegląd i wnioski, Prace Instytutu Lotnictwa, 2014, Vol. 235, 2, pp. 716

[20] Wiśniowski, W., Wolański, P. Rola Instytutu Lotnictwa w badaniach kosmicznych, Prace Instytutu Lotnictwa, 2014, Vol. 234, 1, pp. 9-16, doi: 10.5604/05096669.1106721.

[21] Wolański, P. et Al. Techniques and Technologies of Space Rockets, Warsaw, Institute of Aviation, 2009 